\title{
Opini Audit Sebelumnya, Financial Distress, Auditor Switching dan Opini Audit Going Concern
}

\author{
Kevin Senjaya ${ }^{1}$ \\ I Ketut Budiartha ${ }^{2}$ \\ 1,2Fakultas Ekonomi dan Bisnis Universitas Udayana, Indonesia \\ *Correspondences : senjayakevin02@gmail.com
}

\begin{abstract}
ABSTRAK
Penelitian bertujuan untuk membuktikan apakah opini audit sebelumnya, financial distress, dan auditor Switching pada opini audit going concern. Penelitian ini dilakukan di perusahaan manufaktur yang terdaftar di Bursa Efek Indonesia tahun 20132017. Sampel didapat dengan metode purposive sampling. Jumlah sampel yang diperoleh adalah 43 perusahaan. Teknik analisi data yang digunakan yaitu uji Wald. Berdasarkan hasil penelitian, diketahui bahwa opini audit sebelumnya tidak berpengaruh pada opini audit going concern. Financial distress berpengaruh negatif pada opini audit going concern. Auditor Switching berpengaruh positif pada opini audit going concern. Implikasi teoritis penelitian ini adalah sebagai tambahan referensi penelitian selanjutnya yang berkaitan dengan opini audit going concerndan teori agensi.
\end{abstract}

Kata Kunci: Audit Going Concern; Opini Audit Sebelumnya; Financial distress; Auditor Switching.

\section{Previous Audit Opinion, Financial distress, Auditor Switching and Going concern Audit Opinion}

\section{ABSTRACT}

This study aims to prove whether the previous audit opinion, financial distress, and auditor Switching on going concern audit opinion. This research was conducted in a manufacturing company listed on the Indonesia Stock Exchange in 2013-2017. Samples were obtained by purposive sampling method. The number of samples obtained is 43 companies. The data analysis technique used is the Wald test. Based on the results of the study, it is known that the previous audit opinion has no effect on the going concern audit opinion. Financial distress has a negative effect on going concern audit opinion. Auditor Switching has a positive effect on going concern audit opinion. The theoretical implication of this research is as an additional reference for further research related to going concern audit opinion and agency theory.

Keywords: Going Concern Audit; Previous Audit Opinion; Financial distress; Auditor Switching.

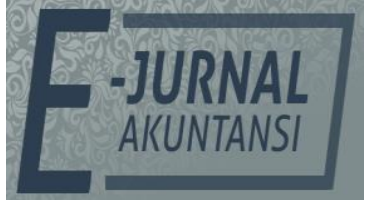

e-ISSN 2302-8556

Vol. 32 No. 1

Denpasar, Januari 2021

Hal. 198-208

DOI:

10.24843/EJA.2022.v32.i01.p14

PENGUTIPAN:

Senjaya, K. \& Budiartha, I. K. (2022). Opini Audit Sebelumnya, Financial Distress, Auditor Switching dan Opini Audit Going Concern. E-Jurnal Akuntansi, 32(1), 198-208

RIWAYAT ARTIKEL:

Artikel Masuk: 18 Oktober 2020 Artikel Diterima: 23 Desember 2021

Artikel dapat diakses : https://ojs.unud.ac.id/index.php/Akuntansi/index 


\section{PENDAHULUAN}

Perusahaan publik secara umum memanfaatkan pasar modal sebagai salah satu sarana dalam mendapatkan sumber dana atau alternatif pembiayaan, sehingga perusahaan berupaya dalam mencari investor yang akan menanamkan modal ke perusahaan tersebut. Investor akan menanamkan modal ke perusahaan apabila investasi yang ditanamkan dapat menghasilkan keuntungan. Perusahaan yang memiliki aset yang besar akan cenderung menghasilkan lebih banyak laba dibandingkan dengan perusahaan dengan aset yang kecil (Fauzan et al., 2019). Dalam praktiknya terdapat banyak kasus manipulasi laporan keuangan yang dilakukan oleh pihak perusahaan untuk menampilkan kondisi perusahaan yang dapat menarik minat investor dalam menanamkan dananya. Tindakan tersebut mengakibatkan investor sulit mempercayai kondisi perusahaan melalui laporan keuangan serta lebih berhati-hati dalam menginvestasikan modalnya pada perusahaan. Berdasarkan kondisi tersebut maka penting bagi perusahaan untuk menyediakan laporan keuangan secara wajar. Berdasarkan penelitian investor akan lebih mudah mempercayai data atau informasi keuangan yang mencerminkan keadaan sebenarnya dari perusahaan. Investor dan pemakai laporan keuangan lain akan lebih mempercayai laporan keuangan yang dikeluarkan perusahaan apabila mencerminkan kinerja dan kondisi keuangan perusahaan dan telah mendapatkan pendapat wajar dari auditor.

Menurut (Winata \& Anisykurlillah, 2018), auditor memiliki tanggung jawab dalam memberikan pendapat atau opini terhadap kewajaran suatu laporan keuangan. Manajemen dan stakeholder mengharapkan opini wajar tanpa pengecualian (unqualified opinion). Karena apabila auditor tidak memberikan opini tersebut, maka mengindikasikan adanya ketidakwajaran dari laporan keuangan yang di audit. Terutama bagi pihak manajemen tentunya sangat menghindari opini selain wajar tanpa pengecualian karena dapat mempengaruhi harga saham perusahaan dan berakibat pada kompensasi yang mereka peroleh (Mais \& Patminingih, 2017). Namun berdasarkan penelitian (Ishak, 2016) menyatakan bahwa, pihak auditor percaya jika mereka mengeluarkan opini selain wajar tanpa pengecualian kemungkinan posisi mereka untuk diganti akan lebih besar.

Opini audit going concern merupakan opini yang diterbitkan auditor untuk memastikan apakah perusahaan dapat mempertahankan kelangsungan hidupnya. Penerbitan opini audit going concern sangat berguna bagi investor dan pengguna laporan keuangan dalam membuat keputusan yang tepat pada saat berinvestasi. Investor mengharapkan keuntungan dari modal yang di investasikan pada perusahaan, sehingga investor tidak menanamkan modalnya pada perusahaan yang mengalami permasalahan keuangan atau financial distress. Keputusan investor di pengaruhi oleh opini auditor dan mengharapkan auditor untuk memberikan early warning mengenai kegagalan keuangan pada perusahaan (Kemuning \& Juliarsa, 2016)

Seorang auditor mempertimbangkan penerbitan opini audit going concern jika auditor menemukan bukti atau keraguan keberlangsungan suatu perusahaan berdasarkan hasil pengujian. Penerbitan opini audit going concern adalah hal yang tidak diharapkan oleh perusahaan karena dapat berdampak negatif pada perusahaan, seperti kemunduran harga saham perusahaan, kesulitan dalam meningkatkan modal pinjaman, serta hilangnya kepercayaan dari pihak investor, 
kreditor, pelanggan, dan karyawan terhadap manajemen perusahaan. Perusahaan yang berpotensi menerima opini audit going concern atauopini audit modifikasi kemungkinkan akan mencari auditor dengan kualitas lebih rendah yang menawarkan opini audit yang diinginkan oleh perusahaan (Eddy et al., 2020)

Fenomena perusahaan manufaktur di Indonesia yang mendapat opini audit going concern adalah kasus Batavia Air tidak bisa membayar hutang $\$ 4,68$ juta yang jatuh tempo pada 13 Desember 2012. Karena Batavia Air tidak melakukan pembayaran, pihak kreditor mengajukan gugatan pailit kepada Batavia Air. Dimana saat sebelum Batavia Air mengalami kebangkrutan, laporan keuangannya menunjukan kemampuan membayar kewajiban jangka pendek serta jangka panjang dan arus kas dalam kondisi baik. Laporan keuangn pun mendapatkan opini audit yang wajar tanpa pengecualian dan menerima kualifikasi going concern pada tahun 2011. Namun, Batavia Air tidak dapat mempertahankan kelangsungan usahanya sehingga mengalami kebangkrutan.

Opini audit going concern memiliki beberapa faktor yang dapat mempengaruhi pertumbuhan perusahaan yaitu opini audit sebelumnya, financial distress, dan auditor Switching. Salah satu faktor tersebut adalah opini audit sebelumnya (Lestari \& Solikhah, 2019). (Kristanti, 2018) menyatakan bahwa auditor dalam menerbitkan opini audit going concernakan mempertimbangkan opini audit going concernpada tahun sebelumnya. Pertimbangan tersebut terjadi jika kondisi keuangan perusahaan tidak menunjukan tanda-tanda perbaikan atau tidak adanya rencana manajemen yang dapat direalisasikan untuk memperbaiki kondisi perusahaan. Berdasarkan opini tahun sebelumnya terdapat gambaran mengenai kondisi pertumbuhan perusahaan terhadap pihak-pihak terkait bahwa perusahaan sedang mengalami kondisi perbaikan baik dari segi ekonomi maupun kegiatan operasional lainnya (Sumadi, 2011)

Selain opini audit sebelumnya, Kesulitan keuangan (financial distress) merupakan suatu kondisi dimana arus kas operasional perusahaan tidak cukup dalam memenuhi kewajiban lancarnya (Kesumojati et al., 2017). Kondisi financial distress pada suatu perusahaan menyebabkan perusahaan mengalami arus kas negatif, rasio keuangan yang buruk serta kegagalan pembayaran hutang. Financial distress pada akhirnya akan mengarah pada kebangkrutan perusahaan sehingga kelangsungan perusahaan akan diragukan, keraguan tersebut mendorong auditor dalam memberikan opini audit going concern pada perusahaan. (Dewayanto, 2011) menyatakan bahwa jika kondisi perusahaan semakin terganggu atau memburuk maka kemungkinan perusahaan menerima opini audit going concern semakin besar. Kondisi kesulitan keuangan atau financial distress dapat dialami oleh seluruh perusahaan, walaupun merupakan sebuah perusahaan yang besar. Kondisi keuangan tersebut dapat menjadi perhatian bagi banyak pihak, tidak hanya pada manajemen perusahaan saja. Kelangsungan usaha dan kondisi keuangan perusahaan dapat menentukan kemakmuran pada berbagai pihak yang memiliki kepentingan terhadap perusahaan (stakeholder), seperti karyawan, investor, pemberi pinjaman, kreditur, pelanggan dan lain-lain. Jika kondisi kesulitan keuangan (financial distress) ini dapat diprediksi lebih dini, maka pihak manajemen perusahaan dapat melakukan tindakan-tindakan yang bisa digunakan untuk memperbaiki kondisi keuangan perusahaan.

Financial distress dapat timbul karena adanya perngaruh dari dalam 
perusahaan sendiri (internal) dan dari luar perusahaan (eksternal). (Aminah et al., 2017) menyatakan beberapa faktor internal yang dapat menyebabkan financial distress, seperti kesulitan arus kas, besarnya jumlah hutang, dan kerugian dalam kegiatan operasional perusahaan selama berapa tahun. Sedangkan, faktor eksternal perusahaan berupa kebijakan pemerintah yang dapat menambah beban perusahaan, seperti kebijakan suku bunga yang meningkat sehingga menyebabkan meningkatnya beban bunga yang ditanggung oleh perusahaan.

Auditor dalam melaksanakan tugasnya harus menjaga independensi serta senantiasa menjalani hubungan kinerja yang baik terhadap kliennya. Salah satu cara untuk tetap menjaga hubungan baik sekaligus menjaga independensi adalah dengan melakukan rotasi audit. (Cameran et al., 2016) menyatakan bahwa, rotasi audit merupakan solusi untuk membatasi hubungan masa kerja yang lama antara auditor dengan klien karena hubungan kerja yang lama ini disinyalir dapat menyebabkan menurunnya kualitas audit. Keruntuhan perusahaan worldcom pada tahun 2000 dan perusahaan Enron pada tahun 2001 di Amerika Serikat menjadi salah satu bukti nyata munculnya skandal akibat hubungan yang terjalin lama antara auditor dengan klien. Skandal tersebut menyebabkan runtuhnya Kantor Akuntan Publik (KAP) yang masuk dalam jajaran lima besar dunia atau Big five. Terjadinya hubungan yang erat antara pihak auditor dengan kliennya mengakibatkan KAP Arthur Anderson terlibat kecurangan di perusahaan worldcom dan Enron yang pada akhirnya membuat KAP tersebut runtuh dan kehilangan independensinya.

Berdasarkan skandal tersebut, banyak negara mulai membenahi struktur pengawasannya terhadap auditor sehingga menetapkan rotasi Kantor Akuntan Publik (KAP) secara wajib dan tidak terkecuali di Indonesia. Hal ini diatur dalam keputusan Menteri Keuangan No. 359/ KMK.06/ 2003 yang kemudian diubah pada tahun 2017 dalam bentuk keputusan menteri keuangan. Dalam pasal 3 ayat 1 peraturan menteri keuangan nomor 13 tahun 2017 tersebut dikatakan: Pihak provinsi yang tidak terdapat KAP atau cabang KAP, persyaratan pengalaman memberikan jasa asuransi atau jasa lain dalam permohonan izin yaitu paling sedikit 500 (lima ratus) jam jasa audit atas informasi keuangan historis dalam 7 (tujuh) tahun terakhir dan 500 (lima ratus) jam jasa lainnya diverifikasi oleh Asosiasi Profesi Akuntan Publik.

Kewajiban perusahaan dalam melakukan rotasi audit berdasarkan peraturan memicu terjadinya auditor Switching pada perusahaan. Auditor Switching adalah pergantian auditor atau KAP yang dilakukan oleh suatu perusahaan yang terjadi karena peraturan permerintah atau berdasarkan keinginan perusahaan. Apabila auditor Switching dilakukan atas keinginan perusahaan, maka pergantian ini bersifat sukarela (voluntary). Namun apabila auditor Switching dilakukan karena peraturan pemerintah, maka pergantian ini bersifat wajib (mandatary). Apabila pergantian auditor dilakukan atas keinginan perusahaan itu sendiri maka terdapat faktor yang mempengaruhi keputusan tersebut (Sumadi, 2011)

Dilandasi dari latar belakang dan rumusan masalah diatas Peneilian ini memiliki tujuan. Untuk memberi bukti empiris apakah financial distress berpengaruh pada opini audit going concern pada perusahaan yang terdaftar di Bursa Efek Indonesia Periode 2013-2017. Untuk memberi bukti empiris apakah 
opini audit sebelumnya berpengaruh pada opini audit going concern pada perusahaan yang terdaftar di Bursa Efek Indonesia Periode 2013-2017. Untuk memberi bukti empiris apakah auditor Switching berpengaruh pada opini audit going concern pada perusahaan yang terdaftar di Bursa Efek Indonesia Periode 2013-2017.

Teori agency pertama kali di temukan oleh (Smulowitz et al., 2019), teori ini menjelaskan hubungan keagenan sebagai kontrak di mana terdapat principal (pemilik) yang terdiri atas satu orang atau lebih melibatkan orang lain (agen) untuk melakukan beberapa layanan atas nama prinsipal dan memberikan beberapa wewenang pengambilan keputusan kepada agen. Teori ini menyatakan bahwa kedua belah pihak yakni prinsipal dan agen akan berusaha memaksimumkan kepentingan atau utilitas mereka sehingga terdapat kemungkinan pihak agen tidak selalu bertindak sesuai dengan kepentingan principal

Teori ini mengutamakan adanya perbedaan atau terpisahnya fungsi antara kepemilikan (principal) dengan fungsi manajemen (agen). Adanya perbedaan atau terpisahnya fungsi ini menyebabkan timbulnya suatu permasalahan atau konflik yang tersebut sebagai masalah keagenan (Agency Problem). Timbulnya konflik ini dikarenakan pihak manajemen memiliki kesempatan untuk mencapai keinginan pribadi mereka dan tentunya mengabaikan kepentingan dan keinginan pribadi meraka dan tentu saja mengabaikian kepentingan dan keinginan dari para pihak pemegang saham sebagai pemilik perusahaan. Auditing merupakan suatu proses sistematis untuk menghimpun dan mengevaluasi bukti-bukti secara obyektif mengenai asersi-asersi tentang berbagai tindakan dan kejadian ekonomi untuk menentukan tingkat kesesuaian antara asersi-asersi tersebut dengan kriteria yang telah menyampaikan hasilnya kepada para pemakai yang berkepentingan (Mus \& Tjan, 2020).

Pengaruh Opini Audit Sebelumnya pada Opini Audit Going concern: Menurut (Kartika et al., 2012) apabila auditor menerbitkan opini audit going concerntahun sebelumnya maka akan semakin besar kemungkinannya perusahaan akan menerima kembali opini audit going concern pada tahun berjalan. Dalam penelitian sebelumnya, menurut (Lestari \& Solikhah, 2019) \& (Dewayanto, 2011) menyatakan bahwa opini audit sebelumnya berpengaruh terhadap opini audit going concern. Dalam (Melistiari et al., 2021) berdasarkan teori agensi, agen akan berusaha untuk memuaskan prinsipal agar mendapatkan reward atas kinerja yang sudah dianggap bagus. Jika suatu perusahaan menerima opini audit going concern pada tahun sebelumnya oleh auditor, maka perusahaan tersebut akan kehilangan kepercayaan diri atas kelangsungan hidupnya dan dalam perumusan teori agensi hal tersebut bukanlah hal yang diinginkan oleh prinsipal atas kerja agen, karena akan mengakibatkan berkurangnya minat para investor untuk melakukan investasi. Oleh karena itu, ketika perusahaan mendapat opini going concern pada tahun sebelumnya maka kemungkinan akan menerima opini going concern pada tahun berjalan semakin besar, karena opini audit sebelumnya menjadi landasan dalam pemberian opini tahun berjalan. Sehingga opini audit sebelumnya berpengaruh positif terhadap opini audit going concern.

$\mathrm{H}_{1}$ : Opini audit sebelumnya berpengaruh positif pada opini audit going concern.

Pengaruh Financial distress pada opini audit going concern. Tahap penurunan 
kondisi keuangan yang dialami perusahaan dan terjadi sebelum terjadinya kebangkrutan atau likuidasi disebut dengan financial distress (Dharmayatri \& Wiratmaja, 2021). Penelitian oleh (Dewayanto, 2011), (Mais \& Patminingih, 2017) dan (Eddy et al., 2020) menghasilkan bahwa adanya pengaruh negatif financial distress yang diproksikan menggunakan model Altman Z-score pada penerimaan opini audit going concern. Hal tersebut karena semakin rendah nilai Z-score maka semakin besar kemungkinanperusahaan tersebut akan menerima opini audit going concern.

$\mathrm{H}_{2}$ : Financal distress berpengaruh negatif pada opini audit going concern.

Pengaruh Auditor Switching pada opini audit going concern. Berdasarkan teori agensi, manajemen sebagai pihak agen diasumsikan memiliki keentingan pribadi dan manajemen memutuskan mengganti auditor. Menurut (Dwiyanti \& Sabeni, 2014) auditor Switching dilakukan karena manajemen menganggap dengan mengganti auditor yang ada, perusahaan dapat menemukan auditor yang memiliki pandangan yang sejalan. (Meliala \& Sulistyawati, 2019) menyatakan, perusahaan akan terus mencari auditor yang memberikan opini yang sesuai dengan harapannya (opinion shopping) dan selama itu perusahaan akan terus memberhentikan auditor yang tidak sesuai dengan harapan. Menurut penelitian (Melistiari et al., 2021)menyebutkan bahwa variabel pergantian auditor berpengaruh signifikan terhadap penerimaan opini audit going concern, hal ini didukung leh hasil penelitian (Nelson, 2014) dan (Eddy et al., 2020) yang menemukan pergantian auditor berpengaruh terhadap penerimaan opini audit going concern. Kurangnya independensi dari auditor lama menyebabkan perusahaan melakukan pergantian audior untuk mendapat opini yang menjelaskan mengenai kelangsungan usahanya.

$\mathrm{H}_{3}$ : Auditor Switching berpengaruh positif pada opini audit going concern.

\section{METODE PENELITIAN}

Pada penelitian ini menggunakan Pendekatan yang digunakan pada penelitia ini adalah asotiatif dengan tipe kasualitas. Pendekatan ini menyatakan pengaruh antara variabel independen yaitu opini audit sebelumnya dan financial distress dan pada variabel dependen yaitu opini audit going concern dengan variabel moderasi yaitu auditor Switching. Objek penelitian ini adalah perusahaan manufaktur yang terdaftar di BEI tahun 2013-2017. Variabel dependen yang digunakan adalah opini audit going concern. Variabel independen dalam penelitian ini menggunakan variabel opini audit sebelumnya, financial distress dan auditor Switching. Dengan menggunakan perhitungan statistik dengan bantuan software SPSS dengan persamaan Analisis Regresi Logistik dalam penelitian ini sebagai berikut.

Ln OGC $/(1-O G C)=\alpha+\beta 1$ OpSebelumnya $+\beta 2$ FD $+\beta 3($ SWITCH $)$.

Keterangan :

Ln OGC/(1-OGC) = Opini audit going concern

a $\quad=$ Konstanta

OpSebelumnya = Opini audit sebelumnya

FD

= Financial distress

(SWITCH)

$\beta_{1}, \beta_{2}, \beta_{3}$

$=$ Auditor Switching

$=$ Nilai dari koefisien regresi 


\section{HASIL DAN PEMBAHASAN}

Regresi logistik uji Wald digunakan menguji ada tidaknya pengaruh dari variabel terikat secara parsial dengan cara membandingkan nilai statistik Wald dengan nilai pembanding Chi square pada derajat bebas $(\mathrm{db})=1$ pada alpha $5 \%$ atau dengan membandingkan nilai signifikansi ( $p$-value) dengan alpha sebesar $5 \%$ dimana $p$ value yang lebih kecil dari alpha menunjukkan bahwa hipotesis diterima atau terdapat pengaruh yang signifikan dari variabel bebas terhadap variabel terikat secara parsial. Hasil uji hipotesis dapat dilihat pada Tabel 1 berikut.

Tabel 1. Hasil Uji Regresi Logistik

\begin{tabular}{llcccccc}
\hline & & B & S.E. & Wald & Df & Sig. & $\operatorname{Exp}(\mathrm{B})$ \\
\hline Step 1 $^{\mathrm{a}}$ & Op.Sebelumnya & $-1,231$ & 1,067 & 1,331 & 1 & 0,249 & 0,292 \\
& FD & $-9,721$ & 2,480 & 15,369 & 1 & 0,000 & 0,000 \\
& SWITCH & 2,691 & 1,123 & 5,736 & 1 & 0,017 & 14,741 \\
& Constant & 24,075 & 6,407 & 14,118 & 1 & 0,000 & $2,855 \mathrm{E} 10$
\end{tabular}

a. Variable(s) entered on step 1: Op.Sebelumnya, FD, SWITCH.

Sumber : Data Penelitian, 2021

Berdasarkan hasil analisis regresi moderasi seperti yang disajikan pada Tabel 1, maka persamaan strukturalnya adalah sebagai berikut .

Ln OGC $/(1-O G C)=24,075-1,231$ Op.Sebelumnya-9,721 FD+2,691(SWITCH)

Nilai signifikansi variabel financial distress dan auditor Switching kurang dari 0,050. Hal ini menunjukkan bahwa variabel financial distress dan auditor Switching berpengaruh terhadap opini going concern, sedangkan opini audit sebelumnya memiliki nilai signifikansi lebih dari 0,05. Hal ini menunjukkan bahwa variabel opini audit sebelumnya tidak berpengaruh signifikan terhadap opini going concernpada perusahaan manufaktur yang terdaftar di Bursa Efek Indonesia dari tahun 2013-2017. Berdasarkan persamaan regresi pada Tabel 1, dapat dijelaskan Nilai konstanta (a) sebesar 24,075 berarti apabila opini audit sebelumnya, Financial distress dan auditor Switching bernilai 0, maka nilai terhadap Opini audit going concernadalah sebesar 24,075. Berdasarkan hasil analisis pengaruh opini audit sebelumnya terhadap opini going concerndiperoleh nilai signifikasi uji wald sebesar 0,249 dengan nilai koefisien Wald negatif sebesar -1,231. Nilai Signifikansi 0,249 > 0,050 mengindikasikan bahwa H0 diterima dan H1 ditolak. Hasil ini mempunyai arti bahwa opini audit sebelumnya tidak berpengaruh signifikan terhadap opini going concern pada perusahaan manufaktur yang terdaftar di Bursa Efek Indonesia periode 2013-2017.

Berdasarkan hasil analisis pengaruh financial distress terhadap opini going concerndiperoleh nilai signifikasi uji wald sebesar 0,000 dengan nilai koefisien Wald negatif sebesar -9,721. Nilai Signifikansi 0,000 $<0,050$ mengindikasikan bahwa H0 ditolak dan $\mathrm{H} 2$ diterima. Hasil ini mempunyai arti bahwa financial distress berpengaruh negatif dan signifikan terhadap opini going concernpada perusahaan manufaktur yang terdaftar di Bursa Efek Indonesia periode 2013-2017. Berdasarkan hasil analisis pengaruh auditor Switching terhadap opini going concerndiperoleh nilai signifikasi uji wald sebesar 0,017 dengan nilai koefisien Wald positif sebesar 2,691. Nilai Signifikansi 0,017<0,050 mengindikasikan bahwa H0 ditolak dan H3 diterima. Hasil ini mempunyai arti bahwa auditor Switching 
berpengaruh positif dan signifikan terhadap opini going concernpada perusahaan manufaktur yang terdaftar di Bursa Efek Indonesia periode 2013-2017.

Hasil uji regresi logistik menunjukkan bahwa opini audit sebelumnya tidak berpengaruh signifikan terhadap opini audit going concern. Hasil ini berarti bahwa ada tidaknya opini audit going concern sebelumnya tidak mempengaruhi auditor untuk memberikan opini going concern saat ini. Temuan ini mendukung penelitian yakni hasil statistik dari penelitian ini tidak berpengaruh tetapi opini audit tahun sebelumnya tetap akan menjadi acuan bagi auditor untuk memberikan pendapat pada periode berjalan. Hal ini menunjukkan bahwasanya belum tentu auditor memberikan pendapatnya yang sama dengan tahun sebelumnya namun tetap melihat kondisi keseluruhan perusahaan pada saat itu, dengan mengamati kondisi keuangan dan kondisi lain yang mendukung untuk memberikan pendapat pada auditee. Penelitian serupa oleh (Sumarwoto, 2014) juga menunjukkan bahwa variabel opini audit sebelumnya tidak berpengaruh pada opini audit going concern.

Berdasarkan teori agensi, agen akan berusaha untuk memuaskan prinsipal agar mendapatkan reward atas kinerja yang sudah dianggap bagus. Jika suatu perusahaan menerima opini audit going concernpada tahun sebelumnya oleh auditor, maka perusahaan tersebut akan kehilangan kepercayaan diri atas kelangsungan hidupnya dan dalam perumusa teori agensi hal tersebut bukanlah hal yang diinginkan oleh prinsipal atas kerja agen, karena akan mengakibatkan berkurangnya minat para investor untuk melakukan investasi, sehingga adanya opini audit going concern tahun sebelumnya bukan berarti menjadi landasan auditor dalam pemberian opini going concern tahun berjalan.

Hasil ini tidak sejalan dengan penelitian (Mus \& Tjan, 2020), (Dewayanto, 2011) serta(Kartika et al., 2012), yang menyatakan bahwa opini audit sebelumnya berpengaruh terhadap opini audit going concern, yakni apabila auditor menerbitkan opini audit going concern tahun sebelumnya maka akan semakin besar kemungkinannya perusahaan akan menerima kembali opini audit going concern pada tahun berjalan.

Hasil menunjukkan bahwa financial distress berpengaruh negatif dan signifikan terhadap opini audit going concern. Hal ini berarti semakin perusahaan mengalami financial distress maka semakin besar kemungkinan perusahaan menerima opini audit going concern. Dengan kata lain, Perusahaan dengan tingkat financial distress yang tinggi menyebabkan semakin besarnya peluang bagi auditor untuk memberikan opini audit going concern. Hal ini disebabkan karena semakin sulitnya keuangan perusahaan dalam melinasi kewajiban-kewajibannya akan menyebabkan kesangsian auditor terhadap kelangsungan hidup perusahaan.

Hasil ini sesuai dengan Teori keagenan (agency theory). Teori agensi menyebutkan adanya hubungan erat agen dengan opini audit going concern. Agen diberikan wewenang oleh prinsipal untuk menjalankan operasional perusahaan dalam menghasilkan laporan keuangan yang akan menunjukkan kondisi keuangan perusahaan dan digunakan sebagai dasar dalam pengambilan keputusan. Agen yang dimaksud pada penelitian ini adalah auditor. Auditor akan mengeluarkan opini audit going concern bila perusahaan mengalami financial distress.

Hasil ini sesuai dengan penelitian oleh (Dewayanto, 2011), (Mais \& Patminingih, 2017) dan (Eddy et al., 2020) menghasilkan bahwa adanya pengaruh negative finansial distress yang diproksikan menggunakan model Altman Z-score 
pada penerimaan opini audit going concern. Hal tersebut karena semakin rendah nilai Z-score maka semakin besar kemungkinanperusahaan tersebut akan menerima opini audit going concern.

Hasil analisis menunjukkan bahwa auditor Switching berpengaruh positif signifikan terhadap Opini Audit Going concern. Hasil ini berarti bahwa semakin tinggi auditor Switching yang dialami perusahaan maka peluang perusahaan menerima opini audit going concernsemakin tinggi. Hasil ini sesuai dengan teori keagenan (agency theory). Teori agensi menyebutkan manajemen sebagai pihak agen diasumsikan memiliki kepeningan pribadi dan ingin memaksimumkan kepentingannya. Dengan otoritas yang dimilikinya manajemen memutuskan mengganti auditor. Menurut (Dwiyanti \& Sabeni, 2014) auditor Switching dilakukan karena manajemen menganggap dengan mengganti auditor yang ada, perusahaan dapat menemukan auditor yang memiliki pandangan yang sejalan. (Meliala \& Sulistyawati, 2019) menyatakan, perusahaan akan terus mencari auditor yang memberikan opini yang sesuai dengan harapannya (opinion shopping) dan selama itu perusahaan akan terus memberhentikan auditor yang tidak sesuai harapan.

Hasil ini sesuai dengan penelitian (Melistiari et al., 2021) menyebutkan bahwa variabel pergantian auditor berpengaruh signifikan tehadap penerimaan opini audit going concern, hal ini didukung oleh hasil penelitian (Nelson, 2014) dan (Eddy et al., 2020) yang menemukan pergantian auditor berpengaruh terhadap penerimaan opini audit going concern. Kurangnya independensi dari auditor lama menyebabkan perusahaan melakukan pergantian auditor untuk mendapat opini audit yang menjelaskan mengenai kelangsungan usahanya. Hasil ini juga sejalan dengan penelitian (Sumadi, 2011) yang menemukan bahwa auditor Switching berpengaruh positif terhadap penerimaan opini audit going concern. Hal ini menunjukkan bahwa perusahaan financial distress yang sebelumnya menerima opini audit going concern cenderung dan melakukan belanja opini cenderung tetap menerima opini audit going concern.

\section{SIMPULAN}

Simpulan yang dapat diberikan berdasarkan hasil penelitian yang dilakukan yaitu Opini audit sebelumnya tidak berpengaruh signifikan terhadap opini audit going concern. Financial distress berpengaruh negatif dan signifikan terhadap opini audit going concern. Auditor Switching berpengaruh positif dan signifikan terhadap opini audit going concern. saran yang dapat dipergunakan sebagai bahan pertimbangan dalam menentukan kebijakan Opini Audit Going concern pada perusahaan manufaktur dimasa mendatang, antara lain Financial distress perlu diminimalisir karena akan memiliki dampak signifikan bagi peningkatan Opini Audit Going concern. Penelitian selanjutnya diharapkan dapat menambah jumlah sampel perusahaan yang akan dijadikan sampel penelitian, misalnya dengan meneliti perusahaan sektor lainnya seperti sektor Bank Umum, BPR, BPD atau bank lainnya. Periode waktu penelitian selanjutnya dapat memperpanjang misalnya lima tahun atau lebih, sehingga dapat dilakukan analisis yang lebih objektif. 


\section{REFERENSI}

Aminah, Werdhaningtyas, A., \& Tarmizi, R. (2017). Analisis Faktor-Faktor Yang Mempengaruhi Auditor Switching Pada Perusahaan Yang Tercatat Di. Akuntansi \& Keuangan, 8(1), 36-50.

Cameran, M., Prencipe, A., \& Trombetta, M. (2016). Mandatory Audit Firm Rotation and Audit Quality. European Accounting Review, 25(1), 35-58. https://doi.org/10.1080/09638180.2014.921446

Dewayanto, T. (2011). Analisis Faktor-Faktor yang Mempengaruhi Penerimaan Opini Audit Going concern Pada Perusahaan Manufaktur yang Terdaftar di Bursa Efek Indonesia. Jurnal Bisnis Dan Akuntansi, 6(1), 81-104.

Dharmayatri, N. W. S., \& Wiratmaja, I. D. N. (2021). Return On Assets, Leverage, Company Size dan Tax Avoidance. E-Jurnal Akuntansi, 31(9), 2301. https://doi.org/10.24843/eja.2021.v31.i09.p12

Dwiyanti, R. M. E., \& Sabeni, A. (2014). Faktor-Faktor Yang Mempengaruhi Auditor Switching Secara Voluntary. Jurusan Akuntansi Fakultas Ekonomi dan Bisnis Universitas Diponegoro. Diponegoro Journal of Accounting, 3, 716723.

Eddy, E. P. S., Angela, A., \& -, E. (2020). The Impact Analysis of Return on Asset, Leverage and Firm Size to Tax Avoidance. Jurnal Akuntansi, 12(2), 256-264. https://doi.org/10.28932/jam.v12i2.2908

Fauzan, F., Ayu, D. A., \& Nurharjanti, N. N. (2019). The Effect of Audit Committee, Leverage, Return on Assets, Company Size, and Sales Growth on Tax Avoidance. Riset Akuntansi Dan Keuangan Indonesia, 4(3), 171-185. https:// doi.org/10.23917/ reaksi.v4i3.9338

Ishak, S. (2016). Going-concern audit report: The role of audit committee. International Journal of Economics and Financial Issues, 6(6Special Issue), 36-39.

Kartika, A., Studi, P., Universitas, A., Kendeng, S. J., Bendan, V., \& Semarang, N. (2012). PENGARUH KONDISI KEUANGAN DAN NON KEUANGAN TERHADAP PENERIMAAN OPINI GOING CONCERN PADA PERUSAHAAN MANUFAKTUR DI BEI The Effect of Financial Condition and Non Financial of Going concern in the Manufacturing Companies Listed at Indonesia Stock Exchange. 1(1), 25-40.

Kemuning, N. L. D., \& Juliarsa, G. (2016). Pengaruh reputasi auditor dan ukuran perusahaan pada keakuratan dalam pemberian opini going concern. E-Jurnal Akuntansi Universitas Udayana, 15(2), 847-861.

KESUMOJATI, S. C. I., WIDYASTUTI, T., \& DARMANSYAH, D. (2017). Pengaruh Kualitas Audit, Financial distress, Debt Default Terhadap Penerimaan Opini Audit Going concern. JIAFE (Jurnal Ilmiah Akuntansi Fakultas Ekonomi), 3(1), 6276. https:// doi.org/10.34204/jiafe.v3i1.434

Kristanti, D. (2018). Implementasi Kebijakan Pengelolaan Pengurus Kelompok Belajar Skema Baru Di Universitas Terbuka. Jurnal Pendidikan Terbuka Dan Jarak Jauh, 19(2), 73-86. https:/ / doi.org/10.33830/ptjj.v19i2.322.2018

Lestari, J., \& Solikhah, B. (2019). The Effect of CSR, Tunneling Incentive, Fiscal Loss Compensation, Debt Policy, Profitability, Firm Size to Tax Avoidance. Accounting Analysis Journal, 8(1), 31-37. https://doi.org/10.15294/aaj.v8i1.23103

Mais, R. G., \& Patminingih, D. (2017). Effect of good corporate governance on tax 
avoidance of the company in listed of the indonesia stock exchange. Jurnal STEI Ekonomi, 26(2), 230-243.

Meliala, H. A. S., \& Sulistyawati, A. I. (2019). PERGANTIAN KANTOR AKUNTAN PUBLIK dan FAKTOR-FAKTOR YANG MEMPENGARUHINYA. Maksimum, $3(1)$, https://doi.org/10.26714/mki.7.1.2017.33-47

Melistiari, N. K. M., Suryandari, N. N. A., \& Putra, G. B. B. (2021). Pengaruh Ukuran Perusahaan, Kondisi Keuangan, Kualitas Audit, Manajemen Laba Dan Opini Audit Tahun Sebelumnya Terhadap Opini .... Kumpulan Hasil Riset ..., 3(1), 1-10. https://ejournal.unmas.ac.id/index.php/kharisma/article/view/1664

Mus, A. R., \& Tjan, J. S. (2020). PARADOKS : JURNAL ILMU EKONOMI Volume 3 . No . 4 ( 2020 ); Oktober Faktor-Faktor yang Mempengaruhi Audit Delay pada Perusahaan Manufaktur yang Terdaftar di Bursa Efek Indonesia. 3(4).

Nelson, M. (2014). Independent Regulatory Agencies. The Presidency $A$ to $Z$, September 2001, 6-8. https:/ / doi.org/10.4135/9781483302782.n158

Smulowitz, S., Becerra, M., \& Mayo, M. (2019). Racial diversity and its asymmetry within and across hierarchical levels: The effects on financial performance. Human Relations, $72(10)$, 1671-1696. https://doi.org/10.1177/0018726718812602

Sumadi, K. (2011). Mengapa Perusahaan Melakukan Auditor Switch? Jurnal Ilmiah Akuntansi Dan Bisnis, 6(1), 1-11.

Sumarwoto, S. (2014). Rotasi Kap Yang Bersifat Mandatory, Kualitas Pelaporan Keuangan Dan Bargaining Power Klien. Jurnal Akuntansi Bisnis Dan Perbankan ..., 22(1). https://jurnal.polines.ac.id/index.php/jabpi/article/view/590

Winata, A. S., \& Anisykurlillah, I. (2018). Analysis of Factors Affecting Manufacturing Companies in Indonesia Performing a Switching Auditor. Jurnal Dinamika Akuntansi, 9(1), 82-91. https://doi.org/10.15294/jda.v9i1.11998 